\title{
SOME MORPHOLOGICAL AND BIOLOGICAL ASPECTS OF LONGNOSED SKATE, DIPTURUS OXYRINCHUS (ELASMOBRANCHII: RAJIFORMES: RAJIDAE), IN SYRIAN MARINE WATERS (EASTERN MEDITERRANEAN)
}

\author{
Hasan H. ALKUSAIRY* and Adib A. SAAD \\ Marine Sciences Laboratory, Faculty of Agriculture, Tishreen University, Lattakia, Syria
}

\begin{abstract}
Alkusairy H.H, Saad A.A. 2017. Some morphological and biological aspects of longnosed skate, Dipturus oxyrinchus (Elasmobranchii: Rajiformes: Rajidae), in Syrian marine waters (eastern Mediterranean). Acta Ichthyol. Piscat. 47 (4): 371-383.
\end{abstract}

Background. Dipturus oxyrinchus (Linnaeus, 1758) is a common skate in Syrian elasmobranch fishery. This species is listed as an Endangered cartilaginous species on the International Union for the Conservation of Nature (IUCN) Red List. Although heavily exploited, until now, no study has been performed on this skate along the Syrian coast in the Levantine basin. This study focuses on the determination of the reproductive period, size at maturity and fecundity of $D$. oxyrhinchus.

Materials and methods. Total length and total weight were determined for 249 specimens of the longnosed skate, captured off Syrian coast. Skates collected were measured and weighed according to standard procedures. Based on the acquired measurements the following relations were determined: disc width-total weight (DW-TW), total weight-total length (TW-TL), total weight-disc width (TW-DW), and total length-disc width (TL-DW). Median size $\left(\mathrm{TL}_{50}\right)$ at maturity was estimated according to commonly accepted methods. Hepatosomatic index (HSI) and gonadosomatic index (GSI) were calculated for males and females. The proportion of the occurrence of developmental stages were noted seasonally. Ovarian fecundity was calculated based on ripe follicles in both ovaries of mature females. Fecundity, expressed as annual egg production per female. Tests for significance $(P<0.05)$ were performed by using ANOVA, Student $t$-test, and the chi-square test. In the relations TW-TL and TW-DW, comparisons of curves were carried out by using ANCOVA

Results. The observed sex ratio was $58.2 \% \div 40.2 \%$ (female $\div$ male). Mean body measurements of females $(n$ $=14)$ were slightly higher than males $(n=8)$. The total length of females ranged from 34.1 to $100.0 \mathrm{~cm}$ and males from 34.5 to $81.6 \mathrm{~cm}$. The total length-total weight, disc width-total weight, and total length-disc width relations were $\mathrm{TW}=0.0009 \mathrm{TL}^{3.35}$ and $\mathrm{TW}=0.0033 \mathrm{DW}^{3.34}$ and $\mathrm{DW}=0.6894 \mathrm{TL}+0.281$, respectively, for all sexes combined. Median size $\left(\mathrm{TL}_{50}\right)$ at maturity were estimated as $\mathrm{TL}_{50}=79.5 \mathrm{~cm}$ for females $(n=149)$ and $\mathrm{TL}_{50}=$ $70.9 \mathrm{~cm}$ for males $(n=100)$. This species had a continuous reproductive cycle. Fecundity was estimated between 50 and 100 egg cases per year.

Conclusion. Information on the reproduction of D. oxyrinchus may allow the decision makers to set appropriate catch limits based on biological reference points, and serves as a baseline in the event of increasing exploitation rates. Especially, this information showed that a possible nursery area maybe established in the Syrian marine waters.

Keywords: maturity, reproductive cycle, fecundity, Syrian coast

\section{INTODUCTION}

Longnosed skate, Dipturus oxyrinchus (Linnaeus, 1758), is a large demersal species found on sandy or muddy bottoms at depths of 90-900 m (Serena 2005, Ebert and Stehmann 2013, Last et al. 2016). Its wide geographical and bathymetric distribution combined with its large body size make this taxon particularly susceptible to fishing pressure, even at low levels of fishing pressure (Dulvy and Reynolds 2002, Mulas et al. 2015). It ranges from the north-east Atlantic, from central Norway to Senegal, including the Faeroe Islands, Skagerrak, the
Canary Islands, Madeira, and the Mediterranean Sea (Serena 2005). It is moderately abundant in the central and eastern Mediterranean Sea, but is now absent from the western Mediterranean (Ellis et al. 2015). Indeed, first indicators of the decline of $D$. oxyrinchus population have been recorded in some Mediterranean regions e.g., Gulf of Lion (Aldebert 1997) and Adriatic Sea (Jukic-Peladic et al. 2001). The IUCN Red List assessed the status of D. oxyrinchus as 'near threatened' (Ellis et al. 2015).

The FAO (FIGIS) database* estimates the Mediterranean and Black Sea production of longnosed

\footnotetext{
* Correspondence: Mr Hasan Alkusairy, Department of Animal Production, Faculty of Agriculture, Tishreen University, Lattakia, Syria, phone: +963932771285, e-mail: (HHA) alkusairyhasan@gmail.com, (AAS)adibsaad52@gmail.com.

${ }^{*}$ http://www.fao.org/fishery/statistics/global-capture-production/query/en
} 
skate to $14 \mathrm{t}$ in 2015 , and the total production of "sharks, rays, and chimaeras" to about $61 \mathrm{t}$ for the Syrian waters in 2015 (i.e., about $3.8 \%$ of the total marine fish production).

Four species of the family Rajidae were recorded off the Syrian coasts: Dipturus oxyrinchus; Raja clavata Linnaeus, 1758; Raja miraletus Linnaeus, 1758; and Raja radula Delaroche, 1809 (see Saad et al. 2006). Dipturus oxyrinchus is commonly captured as bycatch of demersal trawling and longlines throughout the year. In the Mediterranean Sea, there were a few studies on age, growth, biology, feeding behaviour of $D$. oxyrinchus in central Mediterranean; Tunisian coast (Kadri et al. 2014), Sardinian waters (Bellodi et al. 2016, Mulas et al. 2015), and in Saros Bay, northern Aegean Sea (Yigin and Ismen 2010).

No studies have been carried out on the reproductive biology or morphology of D. oxyrinchus in eastern Mediterranean, whereas the lack of detailed biological information for the majority of skate species greatly impedes the development of species-specific management strategies for this group (Ebert et al. 2008).

The purpose of the presently reported study was to provide missing information, concerning both sexes of this fish, on body measurements, fecundity, growth parameters, size at sexual maturity estimates, reproductive cycle characteristics (based on morphological changes in reproductive organs), and the seasonal changes in the frequency of individual developmental stages.

\section{MATERIALS AND METHODS}

Study area and sample collection. A total of 249 longnosed skate, Dipturus oxyrinchus (Fig. 1), were collected from November 2014 through October 2016. All specimens were captured off the Syrian coast, between Raas Albassit and Tartous, $35^{\circ} 55^{\prime} \mathrm{N}$ and $34^{\circ} 55^{\prime} \mathrm{N}$, by trawling and with bottom longlines, on sandy bottoms, at depths ranging from 50 to $300 \mathrm{~m}$ (Fig. 2). Immediately after being captured, the fish were identified, sexed, measured, and weighed.

Morphometric measurements. Measurements were recorded for both sexes to the nearest millimetre following Capapé et al. (2015) and expressed as a percent of total length TL.

Selected biometric relations. Body was weighed (total weight TW) to the nearest gram. Statistical comparison of disc width-total weight and length-weight relations between sexes combined was performed by ANCOVA (version 20, SPSS). The TL-TW and DW-TW relations were determined using the allometric equations:

and

$$
\mathrm{TW}=a \mathrm{TL}^{b}
$$

$$
\mathrm{TW}=a \mathrm{DW}^{b},
$$

respectively ( $n=100$ males, $n=149$ females), TL-DW relation was determined using equation

$$
\mathrm{DW}=a \cdot \mathrm{TL}-b
$$

( $n=249$ males and females)

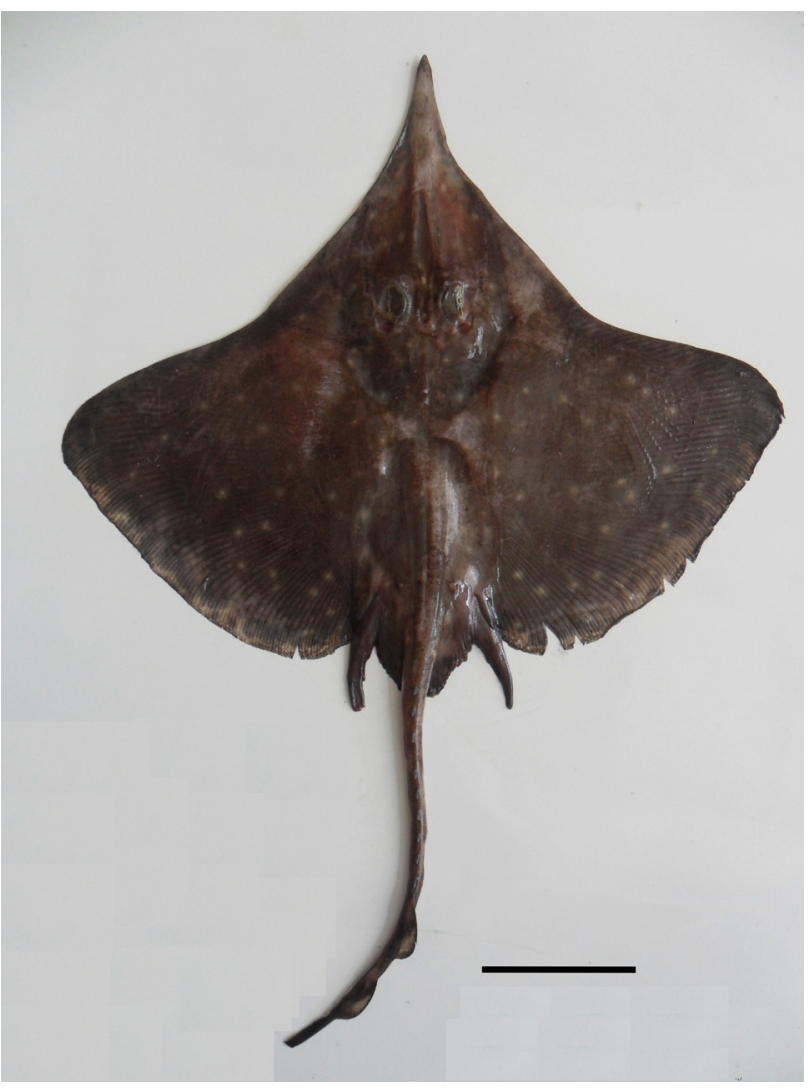

Fig. 1. Specimen of Dipturus oxyrinchus (dorsal surface, female); scale bar $=50 \mathrm{~mm}$

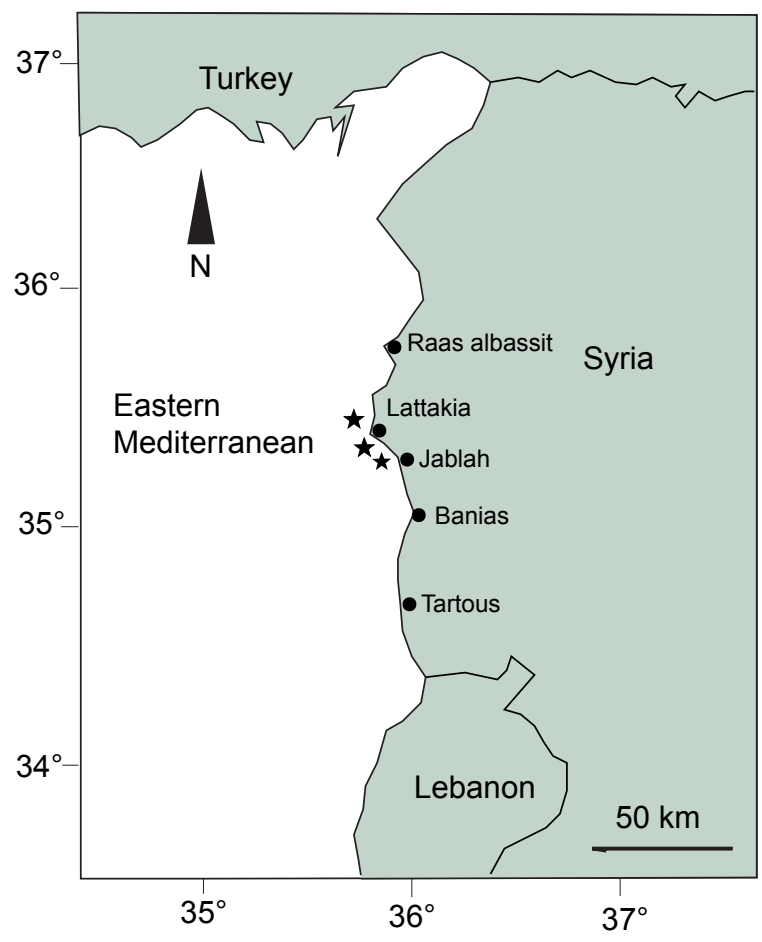

Fig. 2. Capture sites (stars) of Dipturus oxyrinchus off the coast of Syria 
Maturity. The onset of the sexual maturity was determined in males from the condition and the length of claspers measured following Collenot (1969), and some aspects of the testes and other reproductive organs are given following (Anonymous 2010). Size at sexual maturity was determined in females from the condition of ovaries and the morphology of the reproductive tract following (Anonymous 2010). Five developmental stages were distinguished in males: stage 1 (juvenile/immature), stage 2 (developing/immature), stage 3a (spawning capable/mature), stage 3b (actively spawning/ mature), stage 4a (regressing/mature). On the other hand, developing females were divided into six stages: stage 1 (juvenile/immature), stage 2 (developing/immature), stage 3a (spawning capable/mature), stage 3b (actively spawning/mature), stage $4 \mathrm{a}$ (regressing/mature), stage $4 \mathrm{~b}$ (regeneration/mature).

Median sizes at maturity. $\mathrm{TL}_{50}$ and $\mathrm{DW}_{50}$ were estimated by fitting a logistic model to binomial maturity data (Mollet et al. 2000). Data were binned into $1-\mathrm{cm}$ DW and TL size classes females and males were analysed separately. The following form of the logistic equation was fitted using least-squares non-linear regression (version 20, SPSS)

$$
Y=\left(1+e^{-(a+b x)}\right)^{-1}
$$

where $Y$ is the maturity status and $x$ is the total length (or disc width) in centimetres. $\mathrm{TL}_{50}$ and $\mathrm{DW}_{50}$ were calculated from the fitted equation as $-a b^{-1}$ (Mollet et al. 2000).

Reproductive cycle. Hepatosomatic index (HSI) and gonadosomatic index (GSI) were calculated in both males and females, respectively as:

$$
\mathrm{HSI}=100 \mathrm{LW} \cdot \mathrm{TW}^{-1}
$$

and

$$
\mathrm{GSI}=100 \mathrm{GW} \cdot \mathrm{TW}^{-1}
$$

where LW is the liver weight, GW is the gonad weight, and TW is the total weight. Variations in HSI and GSI related to size and to seasons were considered in all stages of specimens in both sexes, with special regard to variations in HSI and GSI related to size. An ANOVA was used to test the null hypothesis of no significant difference between males and females. Additionally, the percentages of stages developing occurrence were noted seasonally.

Fecundity. Ovarian fecundity was calculated based on ripe follicles in both ovaries of mature females. Fecundity, expressed as annual egg production per female, was estimated according to whether females carrying egg capsules were caught (Holden 1975, Oddone and Capapé 2011).

$$
\text { Fecundity }=\sum_{m=1}^{m=12}\left(P_{\mathrm{m}} \cdot P_{\max }^{-1}\right) \cdot\left(N_{\mathrm{m}} \cdot E\right)
$$

where $m$ is month, $P_{\mathrm{m}}$ is the proportion of the capsulecarrying females per month, $P_{\max }$ is the highest proportion capsule-carrying females observed, $N_{\mathrm{m}}$ is the number of days per month, and $E$ is the mean egg laying rate, considering 0.5 eggs per female, based on the observations made by Holden (1975). Due to sampling problems, $P_{\mathrm{m}}$ assumed the value of 0 in some months. In this case, partial fecundity was estimated from last equation and then extrapolated to 12 months to estimate total fecundity.

\section{RESULTS}

Samples description. Of the 249 specimens measured, 100 were males $(42.2 \%)$ and 149 females $(58.2 \%)$ consequently the latter significantly outnumbered the former $\left(x^{2}=9.649\right.$, df $\left.=1, P<0.05\right)$, sex ratio $6 \div 10$ (male $\div$ female). TL in males ranged from 34.5 to $81.6 \mathrm{~cm}$ (DW 23.6-55.6 cm) and in females from 34.1 to $100.0 \mathrm{~cm}$. (DW 23.6-69.0 cm) (Fig. 3).

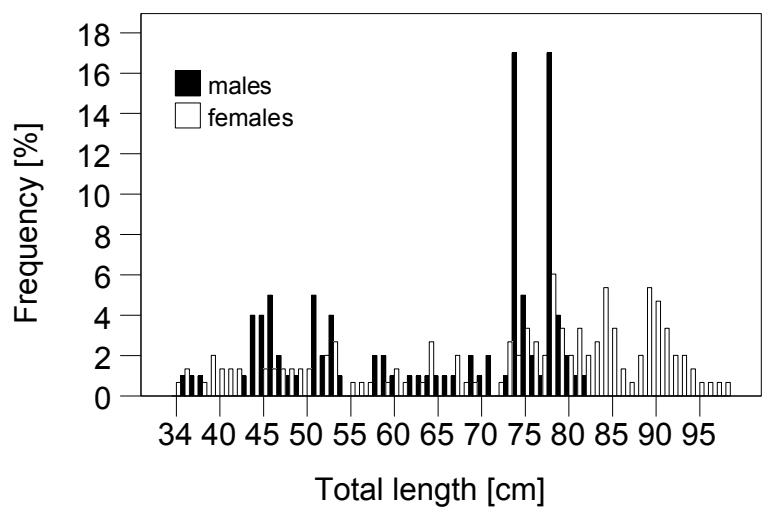

Fig. 3. Total length frequency distribution of Dipturus oxyrinchus sample captured off Syrian coast

Morphometric measurements. A total of 22 specimens (8 males; TL range: $34.5-81.0 \mathrm{~cm}$ and 14 females; TL range: $35.5-79.2 \mathrm{~cm}$ ) of D. oxyrinchus were measured (Table 1). Measurements were compared between the sexes with $t$-tests and differed significantly between the sexes for females ( $t$-test, $t=-3.118, \mathrm{df}=22, P<0.05$ ).

Selected biometric relations. The TL-TW and DWTW relation curves were calculated according to the formula

$$
\mathrm{TW}=a \cdot \mathrm{TL}^{b}
$$

DW-TL relations, however, were determined using the formula

$$
\mathrm{DW}=a \cdot \mathrm{TL}-b
$$

The coefficients determined from the relations are given in Table 2.

By using ANCOVA, the relation between total length (TL) and total weight (TW) showed significant differences between males and females $(F=18.014, \mathrm{df}=1, P<0.05)$. For males the relation (Fig. $4 \mathrm{~A})$ can be expressed as

$$
\mathrm{TW}=0.0005 \mathrm{TL}^{3.51}
$$

For females (Fig. 4B), however, it was

$$
\mathrm{TW}=0.0012 \mathrm{TL}^{3.28}
$$


In addition, the relation between disk width (DW) and total weight (TW) showed significant differences between males and females $(F=15.014$, df $=1, P<0.05)$. For males (Fig. 5A) it was

$$
\mathrm{TW}=0.002 \mathrm{DW}^{3.48}
$$

For females (Fig 5B), however, it was:

$$
\mathrm{TW}=0.0039 \mathrm{DW}^{3.29}
$$

Conversely, the relation between disk width (DW) and total length (TL) did not show significant differences between males and females $(F=2.328$, df $=1, P>0.05)$.

Table 1

Proportional measurements expressed as a percent of total length of males and females of Dipturus oxyrinchus

\begin{tabular}{|c|c|c|}
\hline Measurement & $\begin{array}{c}\text { Males } \\
n=8\end{array}$ & $\begin{array}{c}\text { Females } \\
n=14\end{array}$ \\
\hline Disc width DW & $67.58 \pm 1.26$ & $70.65 \pm 3.20$ \\
\hline Length of disc & $58.75 \pm 1.16$ & $61.20 \pm 2.80$ \\
\hline Snout to max. DW & $38.97 \pm 1.55$ & $36.55 \pm 1.61$ \\
\hline Pre-orbital length & $23.02 \pm 1.77$ & $25.12 \pm 1.78$ \\
\hline Inter-orbital length & $3.80 \pm 0.90$ & $4.00 \pm 0.74$ \\
\hline Inter-spiracle width & $6.32 \pm 0.73$ & $6.27 \pm 0.93$ \\
\hline Pre-spiracle length & $26.79 \pm 0.52$ & $27.73 \pm 1.11$ \\
\hline Pectoral fin anterior margin & $48.61 \pm 1.22$ & $51.27 \pm 2.62$ \\
\hline Pectoral fin posterior margin & $32.46 \pm 1.16$ & $34.99 \pm 2.40$ \\
\hline Pectoral fin inner margin & $7.14 \pm 0.94$ & $6.45 \pm 0.98$ \\
\hline Pre-nasal length & $20.73 \pm 1.15$ & $22.75 \pm 2.15$ \\
\hline Snout to first dorsal fin & $82.22 \pm 1.50$ & $85.10 \pm 3.48$ \\
\hline Snout & $89.36 \pm 1.50$ & $91.54 \pm 3.14$ \\
\hline First dorsal fin base length & $6.00 \pm 0.54$ & $6.02 \pm 0.45$ \\
\hline Second dorsal fin base length & $5.65 \pm 0.45$ & $5.31 \pm 0.16$ \\
\hline First dorsal fin height & $2.69 \pm 0.27$ & $2.72 \pm 0.37$ \\
\hline Second dorsal fin height & $2.33 \pm 0.30$ & $2.32 \pm 0.32$ \\
\hline Inter-nasal width & $7.68 \pm 0.26$ & $7.82 \pm 0.73$ \\
\hline Snout to lip & $25.05 \pm 1.04$ & $27.38 \pm 1.87$ \\
\hline Pre-oral length & $24.11 \pm 2.13$ & $25.67 \pm 1.74$ \\
\hline Mouth width & $7.04 \pm 0.27$ & $7.50 \pm 0.49$ \\
\hline Snout to middle of cloaca & $53.88 \pm 1.32$ & $55.13 \pm 1.55$ \\
\hline Middle of cloaca to tail top & $46.12 \pm 1.32$ & $44.87 \pm 1.55$ \\
\hline
\end{tabular}
captured off Syrian coast

Values are mean $(\%$ of TL) \pm standard deviation.
Consequently, males and females were included in the same relation plotted in Fig. 6, as follows:

$$
\mathrm{DW}=0.69 \mathrm{TL}+0.28
$$

Maturity. A total of 249 specimens of Dipturus oxyrinchus were examined. Among the 149 females classified into maturity stages, $27.52 \%$ were immature (stage 1 , TL; 34.1 $64.0 \mathrm{~cm}$ ), $28.19 \%$ maturing (stage 2, TL; $63.0-88.0 \mathrm{~cm}$ ), while $8.72 \%$ were mature for both spawning capable and actively spawning (stages $3 \mathrm{a}$ and $3 \mathrm{~b}, \mathrm{TL} ; 74.2-100.0$ and $85.0-95.0 \mathrm{~cm}$, respectively), $16.11 \%$ were regressing (stages $4 \mathrm{a}, \mathrm{TL} ; 75.4-92.8 \mathrm{~cm}$ ), and $10.74 \%$ were in the regeneration stage (stage 4b, TL; 81.8-92.2 cm) (Fig. 7B).

Among the 100 males, $36.0 \%$ were immature (stage 1, TL; 34.5-62.5 cm), 12.0\% were maturing (stage 2, TL; 59.0-74.0 cm), 16.0\% were spawning capable (stages 3a, TL; 73.5-81.3 cm, $12.0 \%$ were actively spawning (stages $3 \mathrm{~b}$, TL; $73.5-79.5 \mathrm{~cm}$ ), and $24.0 \%$ were regressing (stage 4a, TL; 63.5-81.6 cm) (Fig. 7A).

Clasper length $(\mathrm{CL})$ increased with stage until stage $3 \mathrm{a}$, stage $1(\mathrm{CL} ; 0.8-3.0 \mathrm{~cm})$, stage $2(\mathrm{CL} ; 1.5-10.1 \mathrm{~cm})$, stage 3a $(\mathrm{CL} ; 8.3-10.3 \mathrm{~cm})$, stage $3 \mathrm{~b}(\mathrm{CL} ; 9.9-15.0 \mathrm{~cm})$, and stage $4 \mathrm{a}$ (CL; 9.8-16.7 cm) (Fig. 8). Significant differences appeared between five stages $(F=279.188, \mathrm{df}=4, P<0.05)$ except mature stages stage 3a-stage $3 \mathrm{~b}(P=0.065)$, stage 3a-stage4a $(P=0.284)$, and stage 4a-stage $3 \mathrm{~b}(P=0.305)$. Similarly, significant differences appeared in the relation DWCL among five stages $(F=3.371, \mathrm{df}=4, P<0.05)$ except between mature stages; stage 3a-stage $3 \mathrm{~b}(P=0.409)$, stage 3a-stage 4a $(P=0.802)$, and stage $4 a-$ stage $3 \mathrm{~b}(P=0.308)$.

The relation of gonad weight $(\mathrm{GW})$ versus $D W$ by maturity stage is presented in Fig. 7. The gonad weight (GW) increased with stage developing until stage $4 \mathrm{a}$ in males, when it regressed, stage 1 (GW; 0.15-3.24 g), stage 2 (GW; 2.02-14.34 g), stage 3a (GW; 9.76-23.09 g), stage 3b (GW; 16.21-23.84 g), and stage 4a (GW; 7.65-16.66 g) (Fig. 9A). There were significant differences between five stages $(F=226.784$, df $=4, P<0.05)$. Significant differences appeared in the relation GW-DW between five stages $(F=226.784, \mathrm{df}=4, P<0.05)$ except mature stages stage $3 \mathrm{a}-$ stage $3 \mathrm{~b}(P=0.409)$, stage 3a-stage $4 \mathrm{a}(P$ $=0.802)$, and stage $4 \mathrm{a}-$ stage $3 \mathrm{~b}(P=0.264)$.

Additionally, the gonads weight GW increased with stage developing until stage $4 \mathrm{a}$ in females, when it regressed, stage 1 (GW; 0.20-3.12 g), stage 2 (GW; 3.11-15.15), stage 3a (GW; 62.97-170.00 g), stage 3b (GW; 106.21-192.00 g), stage $4 \mathrm{a}(\mathrm{GW} ; 10.85-46.10 \mathrm{~g})$, and stage 4b (GW; 57.00-

\begin{tabular}{|c|c|c|c|c|c|c|}
\hline \multirow{2}{*}{ Category } & \multicolumn{2}{|l|}{ DW-TW } & \multicolumn{2}{|l|}{ TL-TW } & \multicolumn{2}{|l|}{ DW-TL } \\
\hline & Relation & $R^{2}$ & Relation & $R^{2}$ & Relation & $R^{2}$ \\
\hline Males & $\mathrm{TW}=0.002 \mathrm{DW}^{3.48}$ & 0.98 & $\mathrm{TW}=0.0005 \mathrm{TL}^{3.51}$ & 0.93 & $\mathrm{DW}=1.41 \mathrm{TL}+1.67$ & 0.97 \\
\hline Females & $\mathrm{TW}=0.0039 \mathrm{DW}^{3.29}$ & 0.98 & $\mathrm{TW}=0.0012 \mathrm{TL}^{3.28}$ & 0.97 & $\mathrm{DW}=1.43 \mathrm{TL}+0.53$ & 0.98 \\
\hline Both sexes & $\mathrm{TW}=0.0033 \mathrm{DW}^{3.34}$ & 0.98 & $\mathrm{TW}=0.0009 \mathrm{TL}^{3.35}$ & 0.96 & $\mathrm{DW}=0.69 \mathrm{TL}+0.280$ & 0.98 \\
\hline
\end{tabular}

Table 2

Selected morphometric relations of Dipturus oxyrinchus captured off Syrian coast

$\mathrm{TL}-\mathrm{W}=$ total length-weight, DW-W = disc width-weight, TL-DW = total length-disc width. 



Fig. 4. Relation between the total weight (TW) and the disk width (DW) for males (A) and females (B) of Dipturus oxyrinchus captured in Syrian marine waters
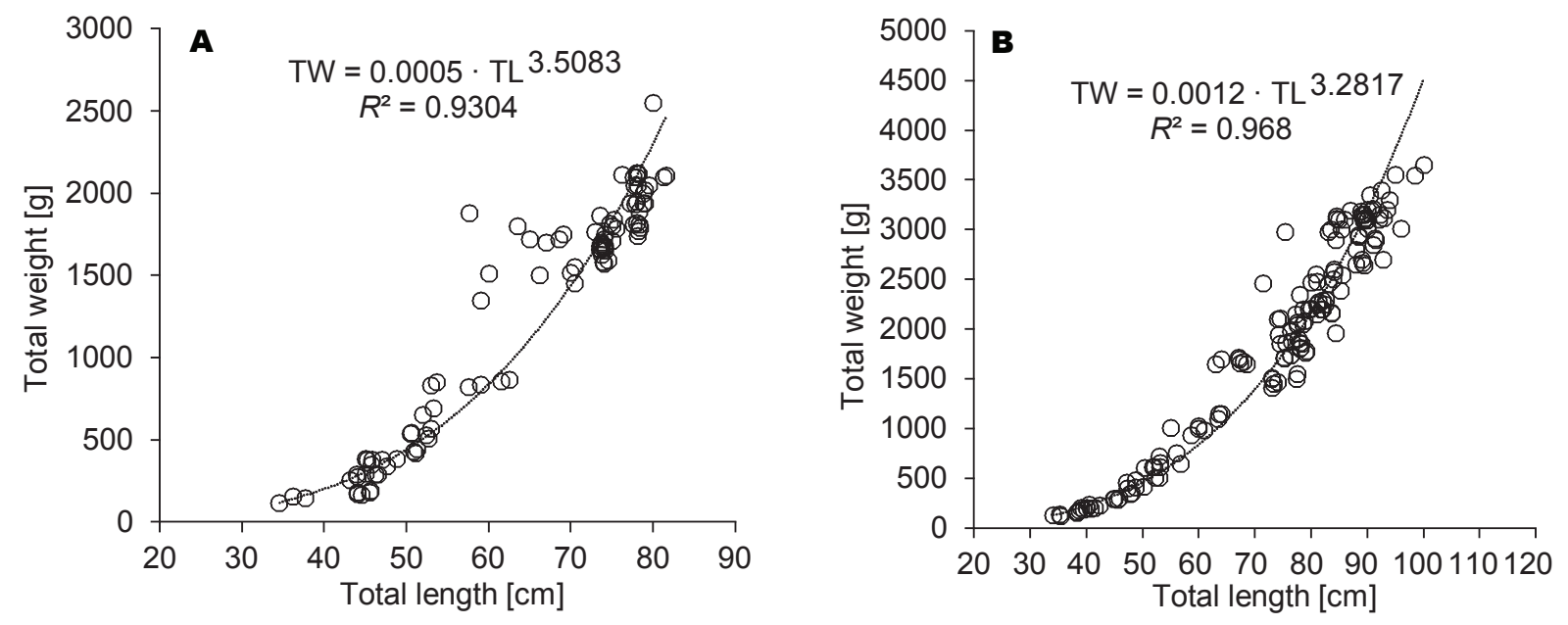

Fig. 5. Relation between the total weight (TW) and the total length (TL) for males (A) and females (B) of Dipturus oxyrinchus captured in Syrian marine waters
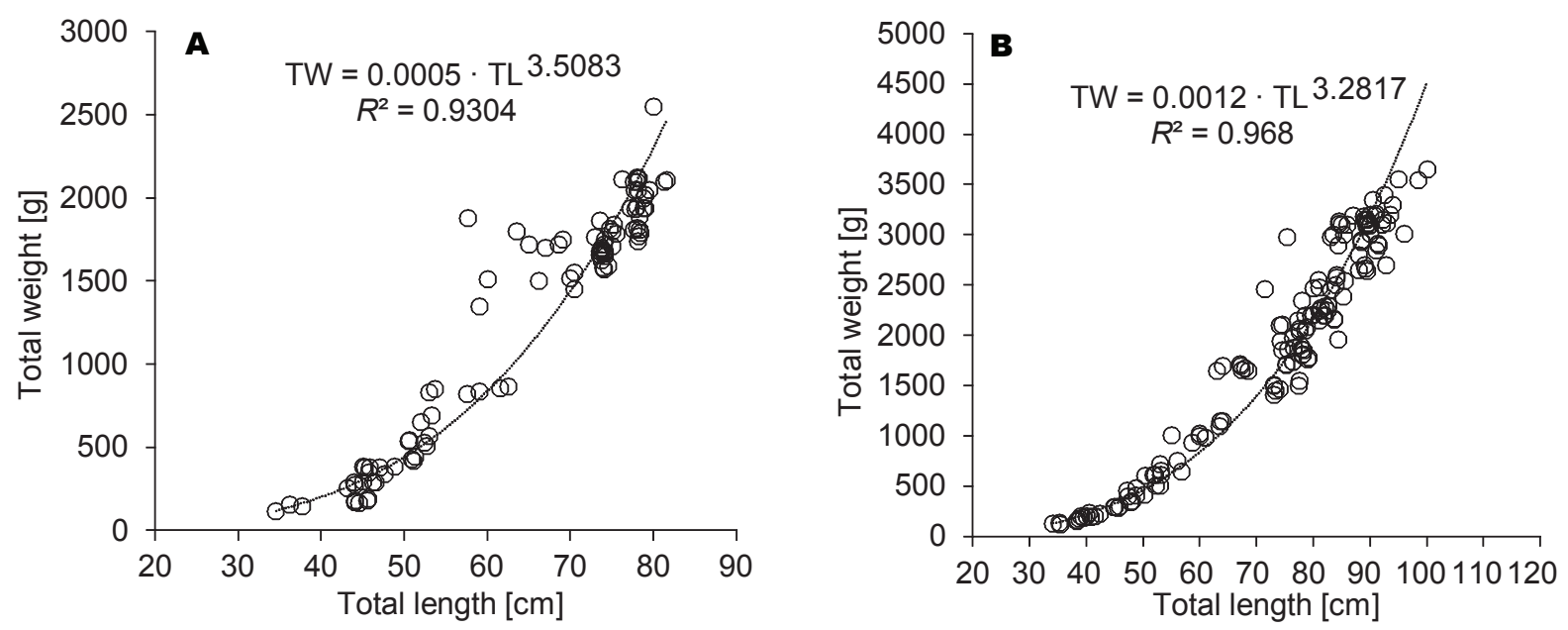

Fig. 6. Relation between the disk width (DW) and the total length (TL) of Dipturus oxyrinchus captured in Syrian waters 
$65.00 \mathrm{~g})$ (Fig. 9B). There were significant differences between six stages $(F=207.851$, df $=4, P<0.05)$, except for immature stages, stage 1 -stage $2(P=0.106)$.

Median disc width $\left(\mathrm{DW}_{50}\right)$ at maturity was estimated as $\mathrm{DW}_{50}=54.8 \mathrm{~cm}$, for females and $\mathrm{DW}_{50}=48.2 \mathrm{~cm}$ for males (Fig. 10A), and median total length $\left(\mathrm{TL}_{50}\right)$ at maturity was estimated as $\mathrm{TL}_{50}=79.5 \mathrm{~cm}$ for females and $\mathrm{TL}_{50}=70.9 \mathrm{~cm}$ for males (Fig. 10B).
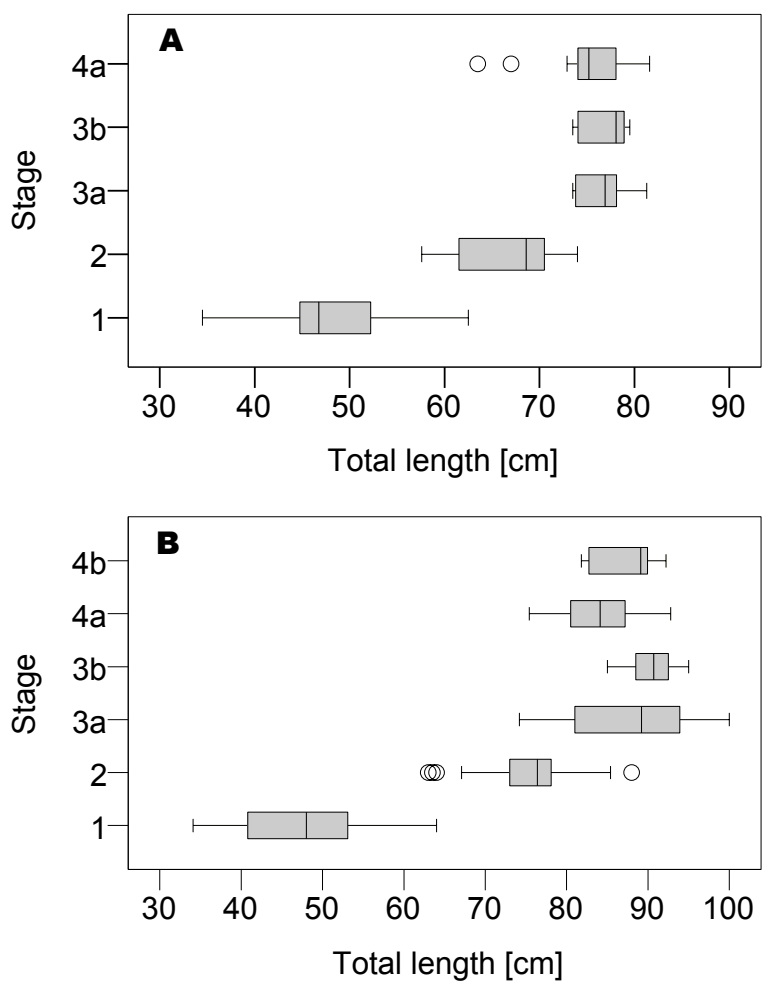

Fig. 7. Box-and-whisker plot with the mean, standard deviation, range of total length for males (A) and females (B) of Dipturus oxyrinchus captured in Syrian marine waters, separately at each maturity stage

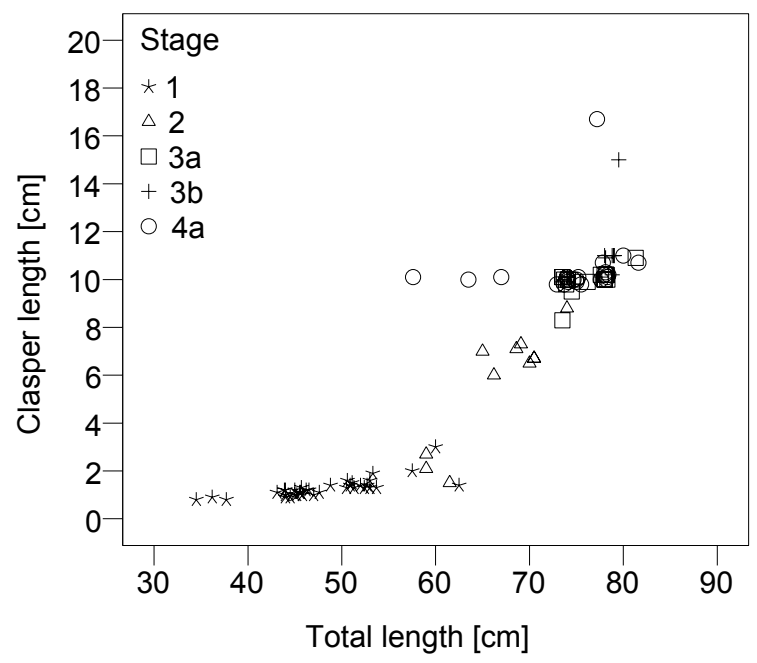

Fig. 8. Relation between the clasper length and the disk width for males of Dipturus oxyrinchus captured in Syrian waters
Reproductive cycle. Considering the whole sample, by using ANOVA, HSI (hepatosomatic index) values no significant differences appeared between males and females HSI values $(F=6.047, \mathrm{df}=1, P>0.05)$ (Fig. 11). Conversely, the females GSI values, were significantly higher than those of males $(F=21.193, \mathrm{df}=1, P<0.05)$ (Fig. 12).

No significant differences appeared in HSI values among the five stages of males $(F=1.981$, df $=4, P>$ 0.05). Conversely, significant differences were noted among the six stages $(F=6.375$, df $=5, P<0.05)$ in females except stage 1-stage $3 \mathrm{a}(P=0.830)$, stage 1 -stage 3b $(P=0.619)$, stage $2-$ stage $4 \mathrm{a}(P=0.301)$, stage $2-$ stage $4 \mathrm{~b}(P=0.347)$, stage $3 \mathrm{a}-$ stage $3 \mathrm{~b}(P=0.819)$, stage $3 \mathrm{a}-$ stage $4 \mathrm{~b}(P=0.138)$, stage $3 \mathrm{~b}-$ stage $4 \mathrm{~b}(P=0.213)$, and stage $4 \mathrm{~b}$-stage $4 \mathrm{a}(P=0.095)$.

GSI (gonadosomatic index) values showed significant differences among the five stages of males $(F=96.259$, $\mathrm{df}=4, P<0.05)$. Additionally, it showed significant differences among six stages $(F=214.896$, df $=5, P<$ $0.05)$ except stage 1 -stage $2(P=0.27)$ in females.

The GSI analysis of adult specimens throughout the year showed that females reach the highest value during the winter and spring (Fig. 13B), while in males, the highest GSI values were in autumn (Fig. 13A). The seasonal evolution of mean HIS values of adults females confirmed the pattern of the GSI, with the highest values in winter and spring (Fig. 14B). In males, no specific trend in HSI was observed (Fig. 14A).

The relative frequency of each maturity stage by season, both for females and males, is shown in Fig. 13. During the sampling period, all maturity stages were recorded, with some variations in their occurrence. Immature male and female specimens were observed throughout the year with a higher percentage of juveniles (stage 1) in spring. Mature females (stage 3a) were found during all seasons with a higher percentage in autumn, females bearing egg cases (stage $3 \mathrm{~b}$ ) found during three seasons winter, spring, and autumn (October to May, except November and April) with a higher percentage in December. Adult regressing females (stages $4 \mathrm{a}$ ) were observed in winter, spring, and autumn (December to June), while adult regeneration females (stage 4b) were observed in summer, winter, and autumn (June to February, except for September and December) (Fig. 15B).

Mature males were present throughout the year with a higher percentage of active specimens (stage $3 \mathrm{~b}$ ) during autumn months (August to December) (Fig. 15A).

Fecundity. The ovarian fecundity in mature females varied from 3 to 30 and from 10 to 26 ripe follicles in right and left ovaries, respectively (mean $\pm \mathrm{SD}, 20.29 \pm 6.82$ for the right ovary and $18.76 \pm 4.64$ follicles for the left ovary). There was no significant difference in the number of follicles between the right and the left ovary (paired $t$-test, $P>0.05)$. The diameter of vitellogenic follicles varied from 5 to $28 \mathrm{~mm}$ with a mean \pm SD size of 11.55 $\pm 6.09 \mathrm{~mm}$.

The number of adult females collected per month is presented in Table 3. Additionally, the mean number of 
egg cases laid by adult female $D$. oxyrinchus was estimated following Holden (1975) (Table 4). The fecundity estimated using the indirect method was 25.45 eggs per females, since no spawning females were sampled in 6 months (Apr-Jun-Jul-Aug-Sep-Nov); total fecundity was extrapolated for 12 months ( $\sim 51$ eggs per females). Holden et al. (1971) had noted that the rate of egg case laying by the thornback ray in aquaria was one egg case per day and this rate was continuous for 26 days. Should D. oxyrinchus produce one egg case per day its annual fecundity could reach 100 , but should egg case production occur every two days, fecundity would be 50 .

\section{DISSCUSSION}

This is the first study to provide information about morphometric relations, reproductive biology, and the fecundity of Dipturus oxyrinchus in eastern Mediterranean. It is estimated that D. oxyrinchus constitutes about $5.11 \%$ (by number) and $1.95 \%$ (by weight) of total landings of batoid fishery off Syrian coast through the period of study, and second most abundant species of skates through the year (Alkusairy and Saad, unpublished data).

Mean values of female measurements of were slightly higher than males, this result may be due to the size of sample (8 males and 14 females), or to stage developing, between eight males six were immature; two were mature, but a total of 14 females were immature.

In the presently reported study, females significantly outnumbered males, whereas according to Yigin and Ismen (2010), Kadri et al. (2014), and Bellodi et al. (2016) both sexes were equally distributed. This might have been the result of the bathymetric distribution by sex and the fishing
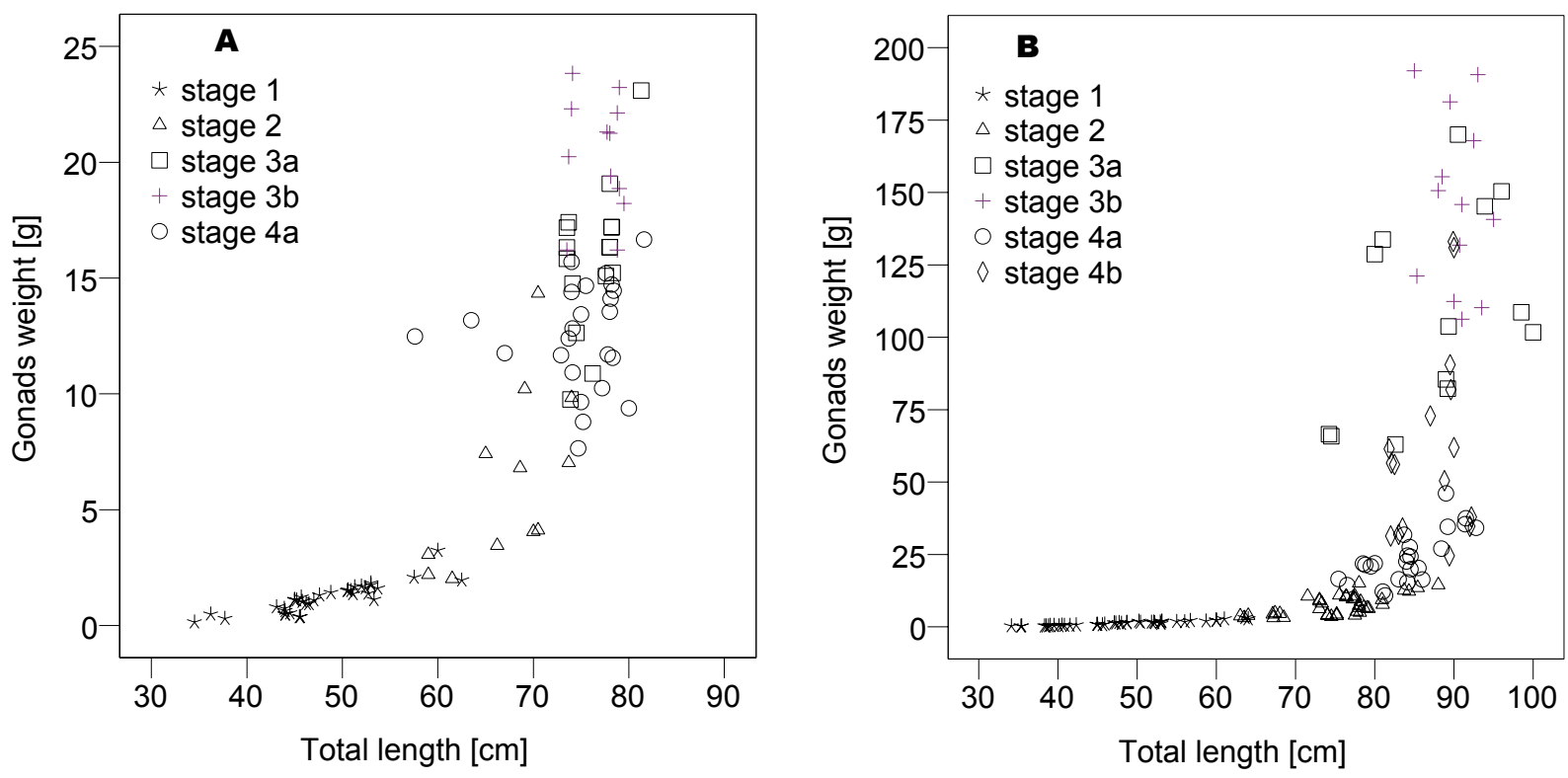

Fig. 9. Relation between the gonads weight and the total length for males (A) and females (B) of Dipturus oxyrinchus captured in Syrian marine waters
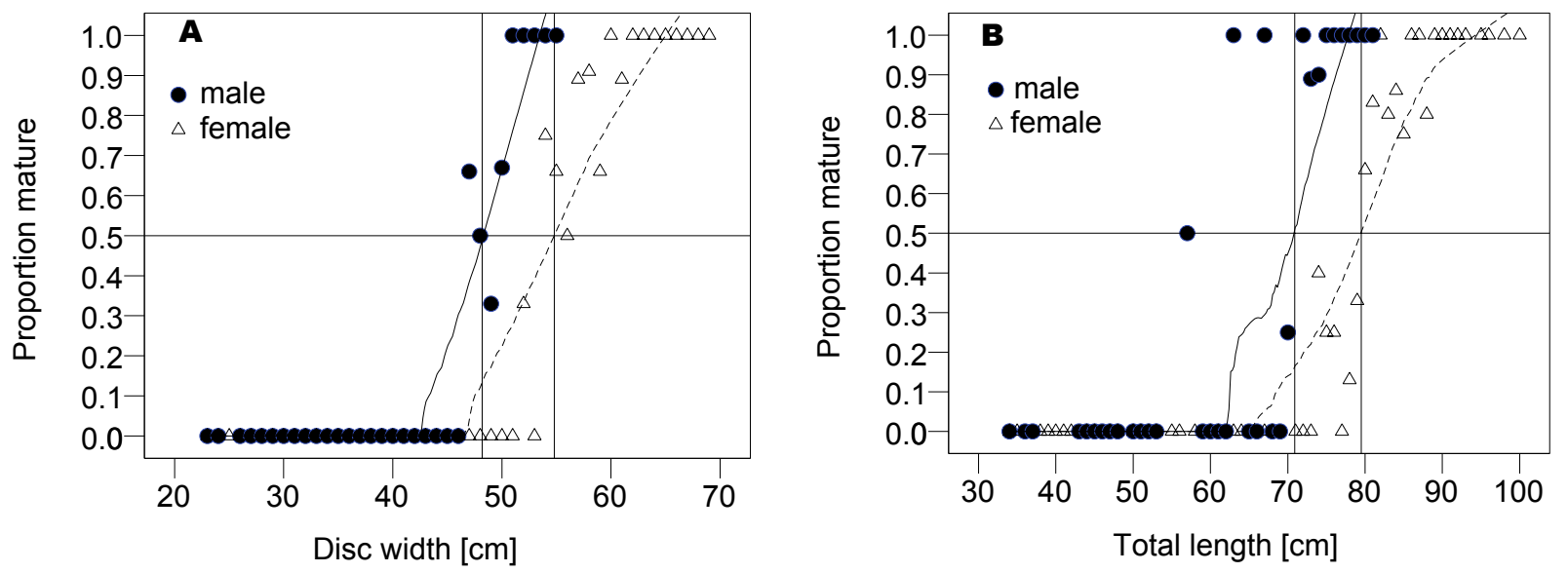

Fig. 10. Relation between maturity status and sizes, disc width DW (A), and total length TL (B) of Dipturus oxyrinchus captured off Syrian waters 


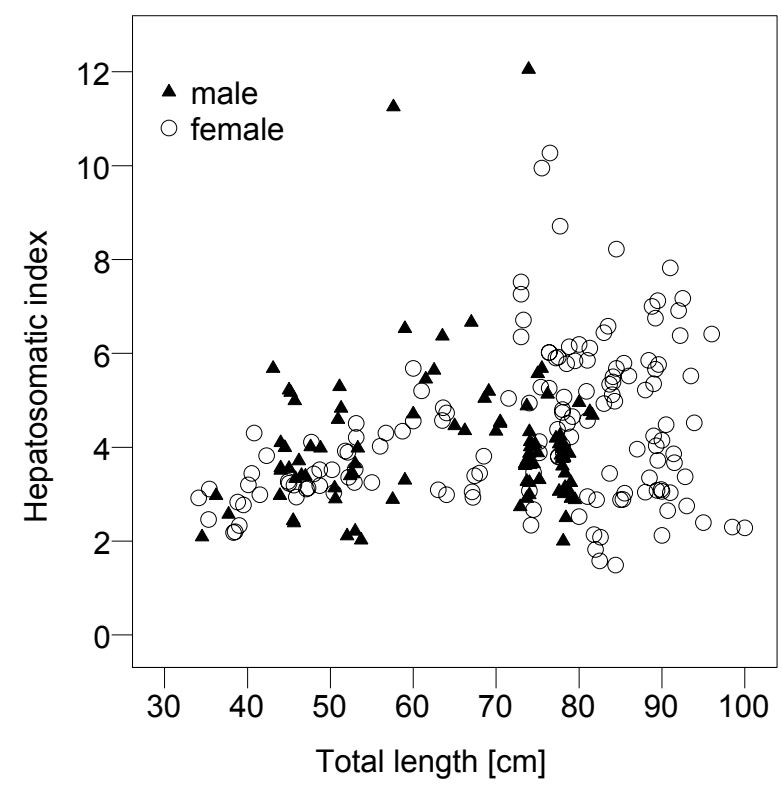

Fig. 11. Relation between the hepatosomatic index and the total length for the male and for female of Dipturus oxyrinchus captured in Syrian marine waters

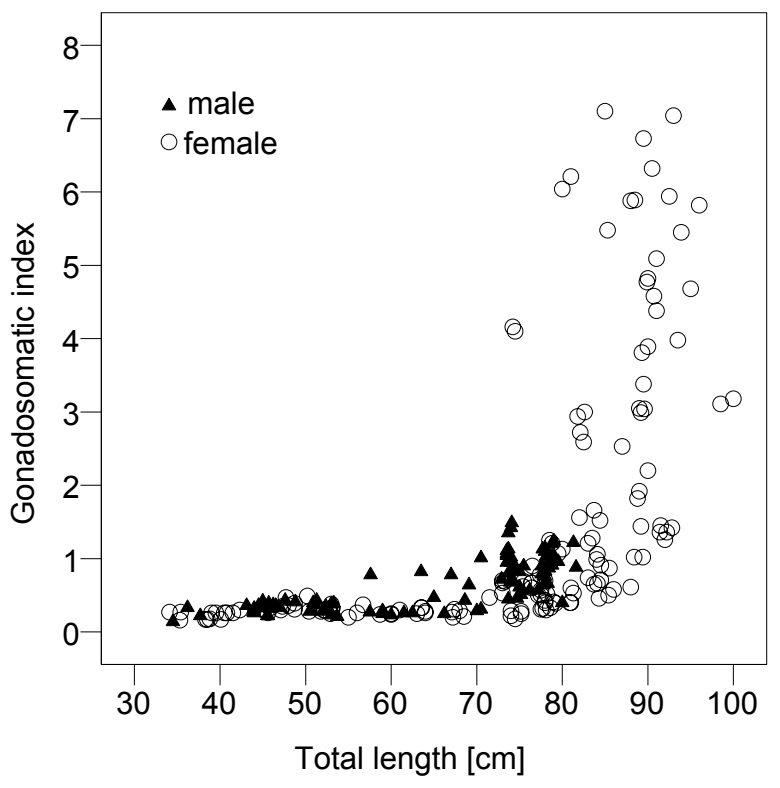

Fig. 12. Relation between the gonadosomatic index and the total length for the male and for female of Dipturus oxyrinchus captured in Syrian marine waters
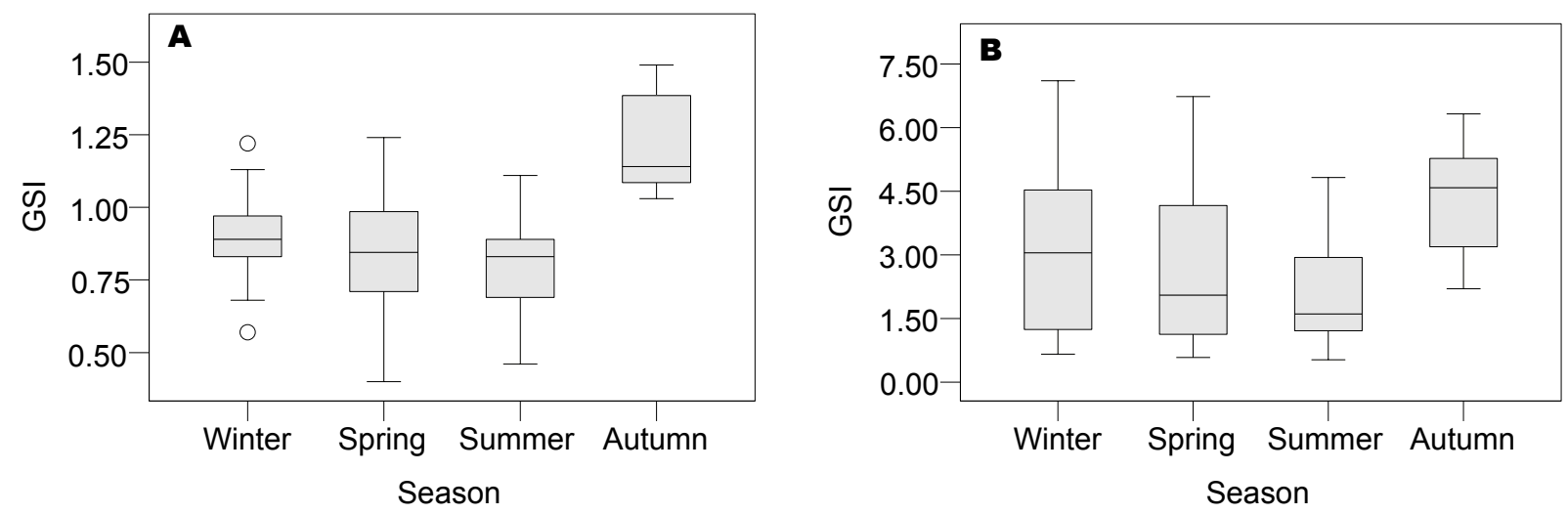

Fig. 13. Seasonal variations of the gonadosomatic index for males (A) and females (B) of Dipturus oxyrinchus captured in Syrian marine waters
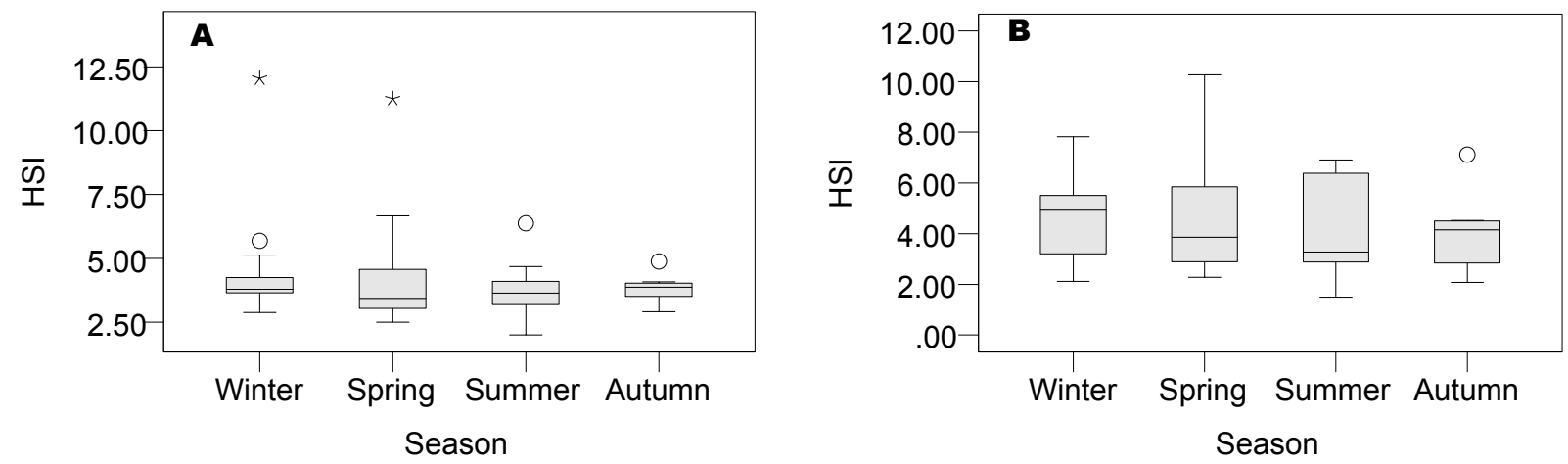

Fig. 14. Seasonal variations of the hepatosomatic index for males (A) and females (B) of Dipturus oxyrinchus captured in Syrian marine waters 

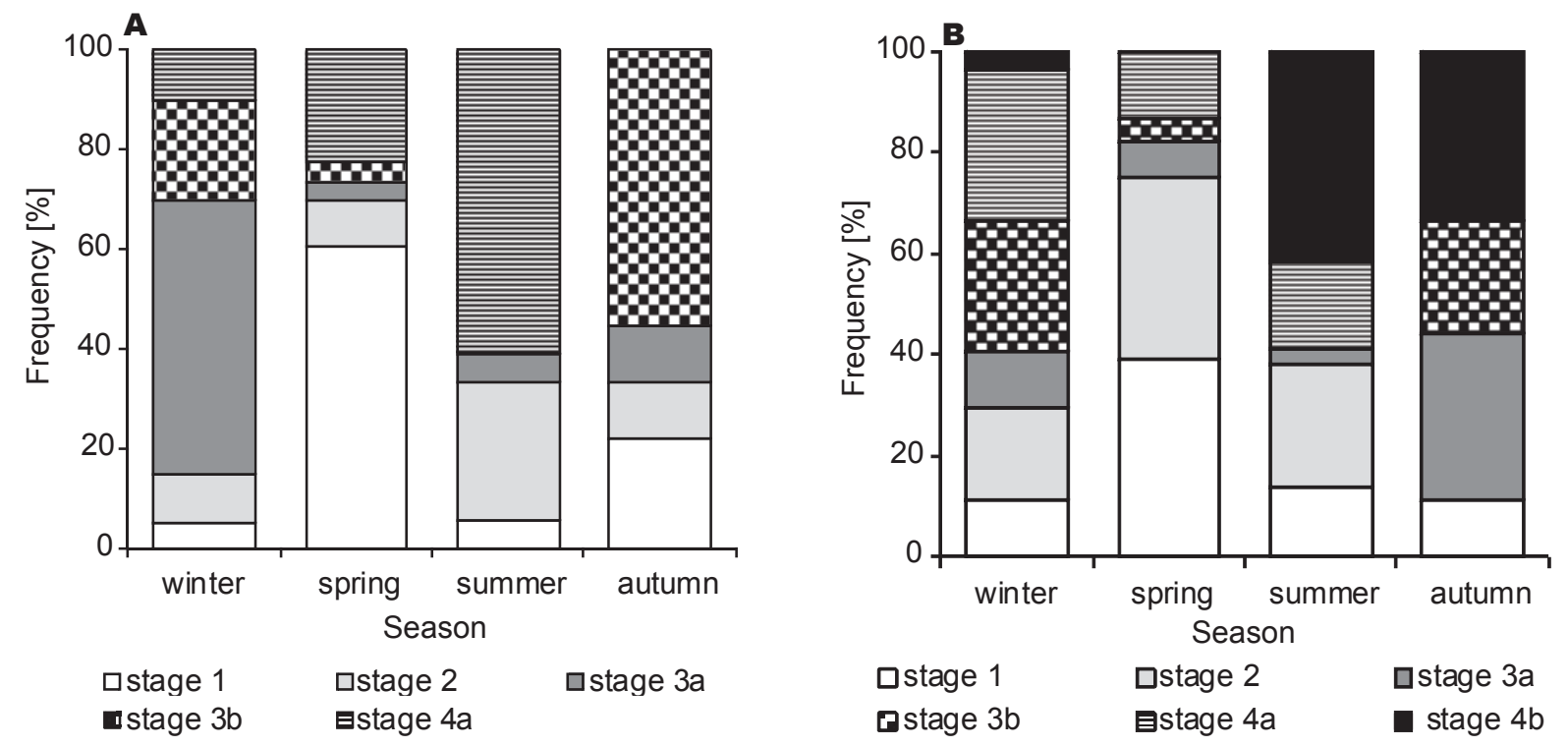

Fig. 15. Seasonal distribution by stages for males (A) and females (B) of Dipturus oxyrinchus captured in Syrian marine waters

gear used, as was also reported for other elasmobranchs such as Gymnura altavela (Linnaeus, 1758) (see Alkusairy unpublished*), Rhinobatos cemiculus Geoffroy SaintHilaire, 1817 (see Ali unpublished $^{* *}$ ). Bellodi et al. (2016) reported that a dominance of $D$. oxyrinchus females was observed in the deepest waters (501-800 m).

In addition, the range size of males was smaller than that of females. The occurrence of sexual differences in growth is well documented in elasmobranchs, with females usually growing larger (Başusta et al. 2008, Yigin and Ismen 2010, Alkusairy et al. 2014, Kadri et al. 2014, Bellodi et al. 2016, Girgin and Başusta 2016, Ali unpublished). Previous studies providing length-weight relations for $D$. oxyrinchus are given in Table 5, for comparative purposes.

In Syrian marine waters, the respective values of TL and DW of D. oxyrinchus at maturity were $70.9 \mathrm{~cm}$, and $48.2 \mathrm{~cm}$ for males and $79.5 \mathrm{~cm}$ and $54.8 \mathrm{~cm}$ for females, corresponding to about $86 \%$ of the maximum values observed TL and DW in males and $80 \%$ of maximum observed TL and DW in females. Cortés (2000) and Ebert (2005) stated that skates tended to mature between $75 \%$ and $90 \%$ of their maximum size. Data reported by Ebert (2005), indicate that this species could be particularly sensitive to fishing pressure and overexploitation.

Large size at maturity, with females maturing larger than males, was previously observed in other Mediterranean areas such as the north Aegean Sea (Y1gin and Ismen 2010), southern Tunisia (Kadri et al. 2014), and Sardinian waters (Bellodi et al. 2016). However, these studies reported larger sizes of $\mathrm{TL}_{50}$, except for Yigin and Ismen (2010) who reported smaller size of $\mathrm{DW}_{50}$ (Table 6). The pattern of difference in size at maturity between regions might be partly explained by differences in sample size, sampling method, and different rates of maturation due to different environmental conditions (Girard and Du Buit 1999), or

Table 3

Seasonal diversity of selected biological parameters of adult females of Dipturus oxyrinchus captured off Syrian coast

\begin{tabular}{|c|c|c|c|c|c|c|c|c|c|c|c|c|}
\hline \multirow{2}{*}{ Biological parameter } & \multicolumn{12}{|c|}{ Month } \\
\hline & Jan & Feb & Mar & Apr & May & Jun & Jul & Aug & Sep & Oct & Nov & Dec \\
\hline \multicolumn{13}{|l|}{ No carrying egg capsules } \\
\hline With yolk and developing oocytes & 2 & 1 & 2 & 4 & - & 1 & 4 & 2 & 1 & 3 & 2 & - \\
\hline With only developing oocytes & 3 & 5 & 8 & 2 & 1 & 9 & - & 2 & - & - & - & 1 \\
\hline Total & 5 & 6 & 10 & 6 & 1 & 10 & 4 & 4 & 1 & 3 & 2 & 1 \\
\hline \multicolumn{13}{|l|}{ Carrying egg capsules } \\
\hline With yolk and developing oocytes & 1 & 1 & 2 & - & 2 & - & - & - & - & 2 & - & 4 \\
\hline With only developing oocytes & - & - & - & - & - & - & - & - & - & - & - & 1 \\
\hline Total & 1 & 1 & 2 & - & 2 & - & - & - & - & 2 & - & 5 \\
\hline Grand total & 6 & 7 & 12 & 6 & 3 & 10 & 4 & 4 & 1 & 5 & 2 & 6 \\
\hline
\end{tabular}

\footnotetext{
"Alkusairy H. 2013. [The study of the life cycle, fecundity, and feed habitat of the cartilaginous species: Gymnura altavela (Linnaeus, 1758) in Syrian marine waters.] MSc Thesis. Tishreen University, Lattakia, Syria. [In Arabic with English abstract.]

${ }^{*}$ Ali M. 2009. [Reproductive biology and feeding of two cartilaginous fish Mustelus mustelus and Rhiobatos cemiculus in Syrian marine waters.] PhD Thesis. Tishreen University, Lattakia, Syria. [In Arabic with English abstract.]
} 
different fishing pressure (Aranha et al. 2009). However, reproductive biology differences with other studies might result of populations or even species differences, indeed it has been suggested that $D$. oxyrinchus could be a species complex as it was demonstrated was for Dipturus batis (Linnaeus, 1758) (see Dulvy et al. 2006).

Seasonally variations were found in the gonadosomatic and hepatosomatic indices of males and females of Dipturus oxyrinchus. The highest values of GSI in females were observed in spring and winter, while in autumn - in males. The highest values of HIS in females were noted

Table 4

Estimated fecundity parameters of females of Dipturus oxyrinchus captured off Syrian coast, following the method of Holden (1975)

\begin{tabular}{lcccc}
\hline & \multicolumn{3}{c}{ Egg cases and rate of laying } \\
\cline { 2 - 5 } Month & $\begin{array}{c}\text { Proportion } \\
\text { with egg } \\
\text { case }\end{array}$ & $\begin{array}{c}\text { Relative } \\
\text { proportion }\end{array}$ & Days & $\begin{array}{c}\text { Number } \\
\text { of eggs } \\
\text { laid }\end{array}$ \\
\hline Jan & 0.20 & 0.04 & 30 & 0.60 \\
Feb & 0.17 & 0.03 & 28 & 0.47 \\
Mar & 0.20 & 0.04 & 31 & 0.62 \\
Apr & 0.00 & 0.00 & 30 & 0.00 \\
May & 2.00 & 0.40 & 31 & 6.20 \\
Jun & 0.00 & 0.00 & 30 & 0.00 \\
Jul & 0.00 & 0.00 & 31 & 0.00 \\
Aug & 0.00 & 0.00 & 31 & 0.00 \\
Sep & 0.00 & 0.00 & 30 & 0.00 \\
Oct & 0.67 & 0.13 & 31 & 2.07 \\
Nov & 0.00 & 0.00 & 30 & 0.00 \\
Dec & 5.00 & 1.00 & 31 & 15.50 \\
Fecundity except (Apr-Jun-Jul-Aug-Sep-Nov) & 25.45 \\
\multicolumn{7}{c}{ Total fecundity } & & 50.90 \\
\hline
\end{tabular}

Proportion with egg case $=$ a ratio of females carrying egg capsules to females no carrying egg capsules, Relative proportion $=$ (rate of laying eggs) $=$ the rate of the proportion of the capsule-carrying females per month to the highest proportion capsule-carrying females observed, Days $=$ number of days in sampling month, Number of eggs laid = mean number of eggs per laid by females sampled in the given month according to mean egg laying rate $E=0.5$. in winter and spring, while in males no specific trend in HSI was observed, probably because they appear to be reproductively active throughout the year. This result has been confirmed by the fact that all maturity stages were recorded throughout the study period, Immature males and females were observed in all sampling seasons with a seasonal peak in spring and females were carrying fully developed oocytes and egg cases throughout the year (except summer months). While some of the hepatic reserves can be used in producing gametes in female oviparous elasmobranch species, the role of the liver in reproduction in male elasmobranchs is still not completely understood (Craik 1978, Garcia-Garrido et al. 1990).

Continuous reproduction throughout the year for Dipturus oxyrinchus was also reported by Kadri et al. (2014) in Tunisian waters and in Sardinian waters (Cabiddu et al. 2012, Bellodi et al. 2016). On the other hand, Stehmann and Burkel (1984) and Notarbartolo di Sciara and Bianchi (1998) reported that the spawning period for this species lasted from February through April, and from February through May (Serena 2005) (Table 6). Continuous reproduction, either with or without seasonal peaks was also suggested for other congeners such as Dipturus nidarosiensis (Storm, 1881) (see Follesa et al. 2012) and several other skate species for example Bathyraja parmifera (Bean, 1881) (see Matta 2015). Year-round reproduction may be a strategy to compensate for late maturity and high maternal energy investment, or it could be a consequence of bet-hedging (Seger and Brockmann 1987), maximizing long-term fitness and increasing the probability of juvenile survival (Bellodi et al. 2016). Spawning active males occurred mainly during the autumn and winter months, and extruding females were mostly found during winter and autumn. This asynchrony suggests that populations could be sexually segregated and mating could occur during to egg-laying, while Bellodi et al. (2016) reported that reproductively active males, however, occurred mainly during the summer months, while reproductively active females were mostly found during autumn and winter.

Oviparous elasmobranchs are not very prolific, as is already known. When skates were compared with that of

Table 5

Principal biometric relations of Dipturus oxyrinchus from different regions

\begin{tabular}{lcrlll}
\hline Length-weight relation & DW-weight relation & \multicolumn{1}{c}{$n$} & \multicolumn{1}{c}{ Sex } & \multicolumn{1}{c}{ Region } & \multicolumn{1}{c}{ Reference } \\
\hline$W=0.0007 \mathrm{TL}^{3.400}$ & - & 8 & Combined & North Aegean Sea & Filiz and Bilge 2004 \\
$W=0.00048 \mathrm{TL}^{3.539}$ & - & 8 & Unsexed & Algarve (S. Portugal) & Borges et al. 2003 \\
$W=0.0009 \mathrm{TL}^{3.34}$ & $W=0.005 \mathrm{DW}^{3.26}$ & 90 & Males & Aegean Sea & Yigin and Ismen 2010 \\
$W=0.0008 \mathrm{TL}^{3.37}$ & $W=0.004 \mathrm{DW}^{3.31}$ & 89 & Females & & \\
$W=1310^{-4} \mathrm{TL}^{3.23}$ & - & 240 & Males & Tunisian waters & Kadri et al. 2014 \\
$W=3510^{-4} \mathrm{TL}^{3.01}$ & - & 380 & Females & & \\
$W=0.0009 \mathrm{TL}^{3.327}$ & - & 448 & Males & Sardinian waters & Bellodi et al. 2016 \\
$W=0 \cdot 0012 \mathrm{TL}^{3.2498}$ & - & 531 & Females & & \\
$W=0.0005 \mathrm{TL}^{3.51}$ & $W=0.002 \mathrm{DW}^{3.48}$ & 100 & Males & Syrian marine waters & This study \\
$W=0.0012 \mathrm{TL}^{3.28}$ & $W=0.0039 \mathrm{DW}^{3.29}$ & 149 & Females & & \\
\hline
\end{tabular}

$\mathrm{DW}=$ disc width, $W=$ total weight, $\mathrm{TL}=$ total length. 
Table 6

Median size at maturity [cm], maximum size [cm] and reproductive cycle of Dipturus oxyrinchus reported from different regions

\begin{tabular}{|c|c|c|c|c|c|c|c|c|c|c|}
\hline \multicolumn{2}{|c|}{$\mathrm{DW}_{50}$} & \multicolumn{2}{|c|}{$\mathrm{TL}_{50}$} & \multicolumn{2}{|c|}{$\mathrm{DW}_{\max }$} & \multicolumn{2}{|c|}{$\mathrm{TL}_{\max }$} & \multirow{2}{*}{$\begin{array}{l}\text { Reproductive } \\
\text { cycle }\end{array}$} & \multirow{2}{*}{ Reference } & \multirow{2}{*}{ Region } \\
\hline$M$ & $\mathrm{~F}$ & M & $\mathrm{F}$ & M & $\mathrm{F}$ & M & $\mathrm{F}$ & & & \\
\hline- & - & $70-80$ & 90 & \multicolumn{2}{|c|}{76 unsexed } & \multicolumn{2}{|c|}{115 unsexed } & - & Ellis et al. 2015 & Italian seas \\
\hline 43.0 & 53.0 & - & - & 57.5 & 65.0 & 86.5 & 100 & - & Yigin and Ismen 2010 & Aegean Sea \\
\hline- & - & 72.05 & 82.1 & - & - & 95.0 & 105.0 & Over the year & Kadri et al. 2014 & Tunisian waters \\
\hline - & - & 91.0 & 103.5 & - & - & 99.5 & 117.5 & Over the year & Bellodi et al. 2016 & Sardinian waters \\
\hline 48.2 & 54.8 & 70.9 & 79.5 & 56.0 & 69.0 & 81.6 & 100.0 & Over the year & This study & Syrian waters \\
\hline
\end{tabular}

$\mathrm{DW}_{50}=$ median disc width $[\mathrm{cm}], \mathrm{TL}_{50}=$ median total length $[\mathrm{cm}], \mathrm{DW}_{\max }=$ maximal disc width $[\mathrm{cm}], \mathrm{TL}_{\max }=$ maximal total length [cm], $\mathrm{M}=$ males, $\mathrm{F}=$ females

other elasmobranch fishes, fecundity in skates would be high, especially in relation to viviparous species (Oddone and Capapé 2011). The fecundity of Dipturus oxyrinchus in Syrian marine waters ranged from 50 to 100 egg cases per year. The fecundity previously assessed for rajoid specimens from British marine waters by Holden et al. (1971) and Holden (1975) was, respectively, 150 and 140 egg cases per year. Capapé (1976) reported a fecundity of 141-167 for $R$. clavata from the northern Tunisian coast and Capapé et al. (2007b) one of between 108 and 162 for specimens from the Languedocian coast, southern France. Capapé and Quignard (1975) noted that the respective fecundity of Raja miraletus and $R$. radula from the Tunisian coast ranged from 40 to 72 and 80 to 154 egg cases. On the other hand, Capapé et al. (2007a) estimated the fecundity range of $R$. miraletus from the Senegalese coast at between 71 and 178 egg cases. Serra-Pereira et al. (2011) noted during spawning season that the total fecundity was around 140 eggs per female of $R$. clavata from Portuguese waters. Oddone and Capapé (2011) reported that fecundity of Rioraja agassizii (Müller et Henle, 1841) ranged from 62 to 124 egg cases per year from south-eastern Brazil. The fecundity estimation of $D$. oxyrinchus falls within the range observed for other rajoid species.

The data in this study, concerning some traits of the reproductive biology of Dipturus oxyrinchus off Syrian marine waters, showed that a possible nursery area of this species was probably established. Conversely, D. oxyrinchus is presumed to be in decline and 'near threatened' in the Mediterranean (Ellis et al. 2015). Finally, all these information, which is confirm a crucial factor to successful conservation and management of the longnosed skate in Syrian marine waters. Similar studies on others species are also needed especially in the region and generally in other Mediterranean regions.

\section{REFERENCES}

Aldebert Y. 1997. Demersal resources of the Gulf of Lion (NW Mediterranean). Impact of exploitation on fish diversity. Vie et Milieu 47 (4): 275-284.

Alkusairy H., Ali M., Saad A., Reynaud C., Capapé C. 2014. Maturity, reproductive cycle, and fecundity of spiny butterfly ray, Gymnura altavela (Elasmobranchii: Lamniformes: Gymnuridae) from the coast of Syria (eastern Mediterranean). Acta Ichthyologica et Piscatoria 44 (3): 229-240.

DOI: 10.3750/AIP2014.44.3.07

Anonymous 2010. Report of the Workshop on Sexual Maturity Staging of Elasmobranches (WKMSEL), 11-15 October 2010, Valetta, Malta. WKMSL Report 2010; ICES CM 2010/ACOM: 48.

Aranha A., Menezes G., Pinho M.R. 2009. Biological aspects of the velvet belly lantern shark, Etmopterus spinax (Linnaeus, 1758) off the Azores, North East Atlantic. Marine Biology Research 5 (3): 257-267.

DOI: $10.1080 / 17451000802433175$

Başusta N., Demirhan S.A., Çiçek E., Başusta A., Kuleli T. 2008. Age and growth of the common guitarfish, Rhinobatos rhinobatos, in Iskenderun Bay (north-eastern Mediterranean, Turkey). Journal of the Marine Biological Association of the United Kingdom 88 (4): 837-842. DOI: $10.1017 / \mathrm{S} 0025315408001124$

Bellodi A., Porcu C., Cannas R., Cau A., Marongiu M.F., Mulas A., Vittori S., Follesa M.C. 2016. Life-history traits of the long-nosed skate Dipturus oxyrinchus. Journal of Fish Biology 90 (3): 867-888. DOI: $10.1111 / \mathrm{jfb} .13205$

Borges T.C., Olim S., Erzini K. 2003. Weight-length relationship for fish species discarded in commercial fisheries of the Algarve (southern Portugal). Journal of Applied Ichthyology 19 (6): 394-396. DOI: $10.1111 / \mathrm{j} .1439-0426.2003 .00480 . x$

Cabiddu S., Atzori G., Mulas A., Porcu C., Follesa M.C. 2012. Reproductive period of Dipturus oxyrinchus (Elasmobranchii: Rajidae) in Sardinian Seas. Biologia Marina Mediterranea 19 (1): 142-143.

Capapé C. 1976. Contribution à la biologie des Rajidae des côtes tunisiennes. III. Raja clavata Linné, 1758: Répartition géographique et bathymétrique, sexualité, reproduction et fécondité. Bulletin du Muséum national d'histoire naturelle, 3 ème série - Zoologie 275 (393): 907-922.

Capapé C., Ali M., Saad A., Alkusairy H., Reynaud C. 2015. Atypical characteristics in the longnosed skate Dipturus oxyrinchus (Linnaeus, 1758) from the coast of Syria (eastern Mediterranean). Thalassia Salentina 37: 71-80. DOI: $10.1285 / \mathrm{i} 15910725 v 37 \mathrm{p} 71$ 
Capapé C., Diatta Y., Seck A.A., Guélorget O. 2007a. Aspects of the reproductive biology of the brown ray Raja miraletus (Chondrichthyes: Rajidae) from the coast of Senegal (eastern Tropical Atlantic). Cahiers de Biologie Marine 48 (2): 169-178.

Capapé C., Guélorget O., Siau Y., Vergne Y., Quignard J.-P. 2007b. Reproductive biology of the thornback ray Raja clavata (Chondrichthyes: Rajidae) from the coast of Languedoc (southern France, northern Mediterranean). Vie et Milieu 57 (1-2): 83-90.

Capapé C., Quignard J.-P. 1975. Essai d'évaluation de la fécondité chez les Sélaciens ovipares: cas de Raja miraletus Linné, 1758 et de $R$. radula Delaroche, 1809 des côtes tunisiennes. Archives de l'Institut Pasteur de Tunis 52 (3): 263-276.

Collenot G. 1969. Etude biométrique de la croissance relative des ptérygopodes chez la roussette Scyliorhinus canicula (L.). Cahiers de Biologie Marine 10 (3): 309-329.

Cortés E. 2000. Life history patterns and correlations in sharks. Reviews in Fisheries Science. 8 (4): 299-344. DOI: $10.1080 / 10408340308951115$

Craik J.C.A. 1978. An annual cycle of vitellogenesis in the elasmobranch Scyliorhinus canicula. Journal of the Marine Biological Association of the United Kingdom 58 (3): 719-726.

DOI: $10.1017 / \mathrm{S} 0025315400041369$

Dulvy N.K., Notarbartolo di Sciara G., Serena F., Tinti F., Ungaro N., Mancusi C., Ellis J. 2006. Dipturus batis. The IUCN Red List of Threatened Species 2006: e.T39397A10198950.

DOI: 10.2305/IUCN.UK.2006.RLTS.T39397A10198950.en

Dulvy N.K., Reynolds J.D. 2002. Predicting extinction vulnerability in skates. Conservation Biology 16 (2): $440-450$

DOI: $10.1046 /$ j.1523-1739.2002.00416.x

Ebert D.A. 2005. Reproductive biology of skates, Bathyraja (Ishiyama), along the eastern Bering Sea continental slope. Journal of Fish Biology 66 (3): 618-649. DOI: $10.1111 / \mathrm{j} .0022-1112.2005 .00628 . x$

Ebert D.A., Smith W.D., Cailliet G.M. 2008. Reproductive biology of two commercially exploited skates, Raja binoculata and $R$. rhina, in the western Gulf of Alaska. Fisheries Research 94 (1): 48-57.

DOI: 10.1016/j.fishres.2008.06.016

Ebert D.A., Stehmann M.F.W. 2013. Sharks, batoids, and chimaeras of the NorthAtlantic FAO Species Catalogue for Fishery Purposes. No. 7. FAO, Rome.

Ellis J., Abella A., Serena F., Stehmann M.F.W., Walls R. 2015. Dipturus oxyrinchus. The IUCN Red List of Threatened Species 2015: e.T63100A48908629.

DOI:

10.2305/IUCN.UK.2015-1.RLTS. T63100A48908629.en

Filiz H., Bilge G. 2004. Length-weight relationships of 24 fish species from the North Aegean Sea, Turkey. Journal of Applied Ichthyology 20 (5) 431-432. DOI: $10.1111 /$ j.1439-0426.2004.00582.x

Follesa M.C., Cannas R., Cabiddu S., Cau A., Mulas A., Porcu C., Cau A. 2012. Preliminary observations of the reproductive biology and diet for the Norwegian skate Dipturus nidarosiensis (Rajidae) from the central western Mediterranean Sea. Cybium 36 (3): 473-477.

Garcia-Garrido L., Muñoz-Chapuli R., de Andres A.V. 1990. Serum cholesterol and triglyceride levels in Scyliorhinus canicula (L.) during sexual maturation. Journal of Fish Biology 36 (4): 499-509. DOI: $10.1111 /$ j.1095-8649.1990.tb03552.x

Girard M., Du Buit M.-H. 1999. Reproductive biology of two deep-water sharks from the British Isles, Centroscymnus coelolepis and Centrophorus squamosus (Chondrichthyes: Squalidae). Journal of the Marine Biological Association of the United Kingdom 79 (5): 923-931. DOI: $10.1017 / \mathrm{S} 002531549800109 \mathrm{X}$

Girgin H., Başusta N. 2016. Testing staining techniques to determine age and growth of Dasyatis pastinaca (Linnaeus, 1758) captured in Iskenderun Bay, northeastern Mediterranean. Journal of Applied Ichthyology 32 (3): 595-601.

DOI: $10.1111 /$ jai.13077

Holden M.J. 1975. The fecundity of Raja clavata in British waters. ICES Journal of Marine Science 36 (2): 110-118. DOI: 10.1093/icesjms/36.2.110

Holden M.J., Rout D.W., Humphreys C.N. 1971.The rate of egg laying by three species of ray. ICES Journal of Marine Science 33 (3): 335-339.

DOI: $10.1093 /$ icesjms/33.3.335

Jukic-Peladic S., Vrgoc N., Krstulovic Sifner S., Piccinetti C., Manfrin G., Marano G., Ungaro N. 2001. Long-term changes in demersal resources of the Adriatic Sea: Comparison between trawl surveys carried out in 1948 and 1998. Fisheries Research 53 (1): 95-104. DOI: $10.1016 / \mathrm{S} 0165-7836(00) 00232-0$

Kadri H., Marouani S., Bradai M.N., Bouaïn A., Morize E. 2014. Age, growth, longevity, mortality and reproductive biology of Dipturus oxyrinchus, (Chondrichthyes: Rajidae) off the Gulf of Gabès (Southern Tunisia, central Mediterranean). Journal of the Marine Biological Association of the United Kingdom 95 (3): 569-577.

DOI: $10.1017 / \mathrm{S} 0025315414000551$

Last P.R., White W.T., de Carvalho M.R., Séret B., Stehmann M.F.W., Naylor G.J.P. (eds.) 2016. Rays of the World. CSIRO Publishing, Clayton, VIC, Australia.

Matta M. E. 2015. Reproductive biology of the Alaska skate Bathyraja parmifera, with comments on an intersexual individual. Journal of Fish Biology 87 (3): 664-678.

DOI: $10.1111 / \mathrm{jfb} .12747$

Mollet F.H., Cliff C., Pratt H.L.jr., Stevens J.D. 2000. Reproductive biology of the female shortfin mako, Isurus oxyrinchus Rafinesque, 1810, with comments on the embryonic development of lamnoids. Fishery Bulletin 98 (2): 299-318.

Mulas A., Bellodi A., Cannas R., Cau A., Cuccu D., Marongiu M.F., Porcu C., Follesa M.C. 2015. Diet 
and feeding behaviour of longnosed skate Dipturus oxyrinchus. Journal of Fish Biology 86 (1): 121-138. DOI: $10.1111 / \mathrm{jfb} .12551$

Notarbartolo di Sciara G., Bianchi I. 1998. Guida degli squali e delle razze del Mediterraneo. [A guide to the sharks and rays of the Mediterranean.] Franco Muzzio Editore, Padova, Italy. [In Italian.]

Oddone C.M., Capapé C. 2011. Annul fecundity assessment for the Rio skate Rioraja agassizi (Chondrichthyes: Arhynchobatidae) endemic to a Neotropical area (southeastern Brazil). Brazilian Journal of Oceanography 59 (3): 277-279. DOI: $10.1590 / \mathrm{S} 1679-87592011000300008$

Saad A., Ali M., Seret B. 2006. Shark exploitation and conservation in Syria. Pp. 202-208. In: Basuşta N., Keskin Ç., Serena F., Seret B. (eds.) The proceedings of the International Workshop on Mediterranean Cartilaginous Fish with Emphasis on Southern and Eastern Mediterranean. 14-16 October 2005, Ataköy Marina, Istanbul. Turkish Marine Research Foundation Publication No. 23. Istanbul, Turkey.

Seger J., Brockmann H.J. 1987. What is bet-hedging? Pp. 182-211. In: Harvey P.H., Partridge L. (eds.)
Oxford Surveys in Evolutionary Biology. Vol. 4. Oxford University Press, Oxford, UK.

Serena F. 2005. Field identification guide to the sharks and rays of the Mediterranean and Black Sea. FAO Species Identification Guide for Fishery Purposes. FAO, Rome.

Serra-Pereira B., Figueiredo I., Serrano-Gordo L. 2011. Maturation, fecundity, and spawning strategy of the thornback ray, Raja clavata: Do reproductive characteristics vary regionally? Marine Biology 158 (10): Article 2187. DOI: $10.1007 / \mathrm{s} 00227-011-1723-6$

Stehmann M., Burkel D.L. 1984. Rajidae. Pp. 163 196. In: Whitehead P.J.P., Bauchot M.L., Hureau J.C., Nielsen J., Tortonese E. (eds.) Fishes of the North-eastern Atlantic and Mediterranean. Vol. 1. UNESCO, Paris.

Yıgın C., Ismen A. 2010. Age, growth, reproduction and feed of longnosed skate, Dipturus oxyrinchus (Linnaeus 1758) in Saros Bay, the north Aegean Sea. Journal of Applied Ichthyology 26 (6): 913-919. DOI: $10.1111 /$ j.1439-0426.2010.01510.x

Received: 10 July 2017

Accepted: 6 November 2017 Published electronically: 31 December 2017 